addressing one of the problematic tendencies or restrictions of this phenomenological model, which is that it understands films primarily as realist, and therefore struggles to distinguish between the cinematic experience and our experience of 'reality'.

The remaining essays explore, in different ways, the representation and experience of the (female, ageing, raced) body, and the spatial orientation, coordination and movement of this body. Sobchack explains that the central theme of the book is 'the embodied and radically material nature of human existence and thus the lived body's essential implication in making 'meaning' out of bodily 'sense." (p. 1) Despite her self-deprecating caveat that it is 'undisciplined', this book's careful argument, its lucid, sometimes intimate style, and an impressive breadth of examples, make a persuasive case for the value of carnal cultural criticism.

doi:10.1057/palgrave.fr. 9400327

Bruce Bennett

\title{
Other Germans: Black Germans and the politics of race, gender and memory in the Third Reich
}

Tina M. Campt; The University of Michigan Press, Ann Arbor, 2004,

ISBN 0-472-11360-7, £13.71 (hbk); ISBN 0-472-03138-4, £14.50 (pbk)

Over the past 20 years a growing number of publications have dealt with the experience of black Germans during the Third Reich, a minority group that has been neglected in histories and historiographies of Nazi persecution. Recent publications range from comprehensive historical studies, such as Clarence Lusane's Hitler's Black Victims: The Historical Experiences of Afro-Germans, European Blacks, Africans, and African Americans in the Nazi Era (2002), to autobiographical accounts such as that by Hans J. Massaquoi, Destined to Witness: Growing up Black in Nazi Germany (1999), which have reached a wider audience. Tina Campt's Other Germans differs from these, as the centre of her study is memory analysis, her aim being to show 'how an examination of the memories of Afro-Germans highlights the workings of memory as a technology that produces not only dominant accounts of history but also the potential for alternative forms of knowledge production and meaning making' (p. 82). Rather than presenting new historical facts, this study explores the complex connections between gender, race and nation, and how Nazi state policies affected subject formations of individual black Germans. Campt achieves this by analysing and interpreting two in-depth interviews that were carried 
out with a male and a female Afro-German in Germany in 1992. Both respondents were what the Nazi regime termed, derogatively, Mischlinge - children of mixed race parents.

To contextualize these interviews, Other Germans starts with an extensive historical introduction. In this, the author explores Germany's responses to racial mixture from the period encompassing Imperial Germany to the Weimar Republic, within the span of which she locates the origins of Germany's treatment of the Mischlinge in the Third Reich. Of particular importance is the occupation of the Rhineland, after the First World War, and the French policy of stationing black soldiers from their colonies within Germany's national boundaries, as it marks the first large-scale presence of people with black skin on German territory. Public reaction viewed this as an added humiliation after they lost the war and focussed mainly on the Blacks' allegedly dangerous sexuality, the threat of interracial sex and subsequent 'miscegenation'. Widely held assumptions of the existence of significant racial differences were taken up by the Nazis and formed the basis for ideas such as the nation needing 'purification from racial pollution'. As part of the drive to preserve 'Aryan stock', about half the 800 Afro-German children living in Germany were forcibly sterilized. Against the historical background of the political, legal and social status and the dominant narrative of collective German memory of Blacks in Germany, the author turns to a highly detailed analysis of the two life-stories which she terms 'memory narratives'.

Her male respondent Hans, born a so-called 'Rhineland Bastard', spent his childhood in the Saarland during National Socialism. Campt extensively analyses the implications of race, military institutions and the process of gendering on this particular individual and his subject formation. What becomes apparent throughout the interview are the tensions of the complex and seemingly contradictory positions Hans occupied in the Nazi period: On the one hand, he asserts that he felt totally integrated into his German community, and even enjoyed his experience as a member of the Hitler Youth. This is juxtaposed with expressions of racial exclusion linked to his forced sterilization at the age of 15 . Although rejected as a racially impure individual, paradoxically, he was later called up for service in the German Army, which he accepted despite his feeling of being 'different'. Army and uniform not only offered him the chance of survival, but also acceptance as an equal among 'Aryan' soldiers, hence proving his masculinity.

The female respondent, Fasia, has a history unrelated to the occupation of the Rhineland. Born in 1929 to a German mother and a Liberian diplomat in Hamburg, she grew up in a politically conscious household, her stepfather being a communist. As a Mischling, she was expelled from dance academy on racial grounds and was made to spend her Pflichtjahr (compulsory service year) as a kitchen hand in Rothenburgsort, a female concentration camp. After the war she 
became a singer and peace activist. Despite the regime's attempts to exclude her, and the negation of her being part of the German collective, her unequivocal identification as German is most striking in her oral account. Her descriptions of different spaces and her interactions shed light on some of the ways in which dividing humans on the basis of race worked in the Nazi period.

The focus on the minute details of these two narrative accounts and the application of theoretical tools, allows Campt to show the connection of two ordinary black Germans to the larger systems that shaped their lives. Both narratives provide vivid accounts of the unsystematic nature of the Nazi policy towards black people in Germany, and the extent of their persecution depended much on local politics and the individual's ties within their community. However, a pressing question arises in this context: Why did the ambivalent and incoherent racial policy towards Blacks not apply equally to other 'non-Aryan' groups - such as the 'Gypsies'? On what basis were Blacks affected differently? Was it perhaps their relatively insignificant number, or the lack of a Black community that saved many from extermination? Although not the focal point of this study, answers to such questions would have added to a fuller contexualization of this persecuted minority group. The clear strength of Other Germans lies in the careful narrative analysis of the remarkable cases. Campt depicts a complex picture that shows how it was possible for her respondents to be in ambivalent positions during the Nazi period, as both outsider and insider. However, one feels that in certain passages the author could have probed into this issue further to elicit deeper insights into the intricacies of the interviewees' double status as victims and persecutors. It would have been interesting, for example, to know more of Hans's role and his actions in the Army or Fasia's recollections of her contact with the Jewish women in the concentration camp.

In the last chapter, Other Germans draws on a very interesting contemporary discussion of the concept of the African Diaspora. Campt reflects on her own experience as an Afro-American woman and on those of her Afro-German interviewees; her analysis challenges the widespread notion that diasporic links are necessarily existent in all black people. She contends that 'diasporic relations are highly constructed processes of cultural reading and interpretations that shape our ability to understand the differences between different histories and cultures' (p. 210).

Other Germans is a fascinating book that also contains in the appendix the original transcripts of the interviews in German, and it should appeal to anyone who is interested in oral history, memory and identity work, particularly in the context of race and gender formation in the Third Reich. 